\title{
Simulation of macroamylasaemia by salivary-type ('S type') hyperamylasaemia
}

\author{
J. E. BERK ${ }^{1}$, L. FRIDHANDLER, AND K. MONTGOMERY \\ From the Department of Medicine, College of Medicine, University of California, Irvine, California
}

SUMMARY Hyperamylasaemia with low or normal urinary amylase excretion in the face of normal renal function has been noted to be indirect evidence for the existence of macroamylasaemia. A more refined indicator is a low ratio of renal amylase clearance to creatinine clearance. This report describes observations made in three patients, each of whom displayed the indirect features suggestive of macroamylasaemia. In none of these patients, however, could a serum macroamylase be demonstrated by chromatography. Ultracentrifugation was also done in one of the patients and likewise failed to disclose a macroamylase in the serum. When the isozyme nature of the serum amylase in each of these patients was examined, there was found to be a marked rise in activity of the salivarytype isoamylase ('S-type amylase'). The pancreatic-type isoamylase ('P-type amylase') was normal in one patient and perhaps slightly above normal in the other two. These data indicate that (1) S-type hyperamylasaemia may exhibit the indirect criteria taken to indicate macroamylasaemia and thereby simulate the latter disorder; and (2) unequivocal identification of macroamylasaemia requires the direct demonstration of the presence in the serum of a macromolecular amylase complex.

The features originally identified for hyperamylasaemia were the occurrence of hyperamylasaemia with low or normal urinary amylase excretion in the face of normal renal function (Berk, Kizu, Take, and Fridhandler, 1970; Berk, Kizu, Wilding, and Searcy, 1967). These characteristics were considered to be hallmarks of the disorder and valuable indices of its existence. Subsequently, Levitt and his associates (Levitt, Rapoport, and Cooperband, 1969) refined these criteria by relating the clearance of amylase to the clearance of creatinine by the kidneys. They pointed out that in the presence of macroamylasaemia, the ratio of renal amylase clearance to creatinine clearance was low and that this reduced ratio provided an indicator of the existence of macroamylasaemia. That these several characteristics are not invariably present became evident when a survey that we made using a rapid screening method (Fridhandler, Berk, and Ueda, 1971) disclosed the presence of a macroamylase in some sera even though the total serum amylase activity in these sera was within normal limits

${ }^{1}$ Address for reprint requests and correspondence: J. Edward Berk, MD, Department of Medicine, University of California, Irvine, California, 92664 USA

Received for publication 20 June 1973.
(Barrows, Berk, and Fridhandler, 1972). The data comprising the basis for the present report further demonstrate that the biochemical alterations that are classically associated with macroamylasaemia are not absolute indices of that disorder. Described herein are observatiens made in three patients displaying the biochemical features indirectly suggestive of macroamylasaemia who were found instead to have a predominant increase in salivarytype isoamylase.

\section{Patients and Methods}

Amylase content was measured and the isoamylase pattern analysed in the serum and urine of three patients referred for examination primarily because of demonstrated hyperamylasaemia and suspected macroamylasaemia.

\section{PATIENTS}

\section{Case 1}

S.B. was a 46-year-old black man with haemoglobin CC disease and gout who consumed large amounts of alcohol. Physical examination disclosed jaundice, markedly enlarged parotid glands, a precordial systolic murmur, and a palpably enlarged, firm 
spleen. Haemoglobin was $8.6 \mathrm{mg} / 100 \mathrm{ml}$ and the platelet count was $60000 / \mathrm{m}^{3}$. The serum amylase ranged from 487 to 1278 Somogyi units. Urinary amylase output per 24 hours, repeated on several occasions, yielded a maximal value of 2862 units. Creatinine clearance on two occasions gave values of 59 and $66.5 \mathrm{ml} / \mathrm{minute}$, respectively.

\section{Case 2}

L.W., a 62-year-old white woman, presented with a six-year history of recurrent epigastric and periumbilical pain before meals. She was known to be diabetic and had also been diagnosed as having arthritis for which she was taking salicylates. Examination disclosed intermittent swelling of the submandibular glands and an enlarged thyroid containing a nodule in the left lower pole. Serum amylase values were found to range between 275 and 437 Somogyi units. The 24-hour urine amylase output, determined on two occasions, was only 294 and 132 Somogyi units, respectively. Serum creatinine was $1.1 \mathrm{mg} / 100 \mathrm{ml}$ and a creatinine clearance gave a value of $95 \mathrm{ml} /$ minute.

\section{Case 3}

I.N., a 54-year-old white woman, was initially seen in February 1967 because of abdominal pain and found to have a serum amylase of 362 Somogyi units. Cholecystectomy had been done three years previously because of supposed pancreatitis. A gastric resection and vagotomy was done in 1968 for reasons not established and in January 1972 she was operated on again for 'adhesions'. In May 1972 she was again examined because of recurrent abdominal pain. Physical examination was unremarkable aside from moderate tenderness in the right upper quadrant of the abdomen. Serum amylase determinations done on several occasions gave values ranging from $\mathbf{5 1 0}$ to 834 Somogyi units. Urinary amylase output was 210 units/hour. Blood urea nitrogen was $15 \mathrm{mg} / 100$ $\mathrm{ml}$ and serum creatinine was $0.8 \mathrm{mg} / 100 \mathrm{ml}$.
Creatinine clearance was $61.3 \mathrm{ml} /$ minute. The abdominal pain improved with anticholinergic medication.

\section{Methods}

Each serum sample was examined for the presence of a macroamylase by a rapid screening method that features the use of microcolumn ' dextran gel chromatography (Fridhandler et al, 1971). Each sample was examined as well by dextran gel chromatography employing larger columns and an automated amylase assay (Fridhandler and Berk, 1970). Ultracentrifugation (Ueda, Berk, and Fridhandler, 1971) was additionally done on the serum obtained from one of the patients (S.B.). The isoamylase pattern of each of the serum samples was determined by a method recently described by us (Fridhandler, Berk, and Ueda, 1972). This method features separation of amylase from other serum proteins by passage through a column of dextran gel (Sephadex G100) and then passage of the purified amylase through another column containing an ion exchange preparation (DEAE Sephadex A50). The total serum amylase activity and the activity confined to the two principal types of amylase obtained from the ion exchange column ('P-type' and 'S-type') were quantitated.

Urine amylase activity was determined in each urine sample by the same automated assay method used for measuring serum amylase activity (Fridhandler and Berk, 1970). Total amylase output in the urine per hour was computed from analysis of the amylase content of two-hour urine samples.

Amylase clearance was determined from the values of amylase found in the serum and urine. Creatinine was also measured in the serum and urine samples and creatinine clearance estimated from these values. The ratio of amylase to creatinine clearance was then determined after the method of Levitt et al (1969).

\begin{tabular}{|c|c|c|c|c|c|c|}
\hline \multirow[t]{2}{*}{ Subject } & \multicolumn{3}{|c|}{ Serum Amylase ${ }^{1}$} & \multicolumn{2}{|l|}{ Urine Amylase } & \multirow{2}{*}{$\frac{\mathrm{Cam}}{\mathrm{Ccr}} \times 100$} \\
\hline & Total & S-type & $P$-type & Concentration & Output/hr & \\
\hline
\end{tabular}

Table Serum and urine amylase values, isoamylase composition of serum amylase, and renal amylase to creatinine clearance ratios in patients with predominantly S-type hyperamylasaemia

${ }^{2}$ Values represent reducing power expressed as $\mathbf{m g}$ of glucose. Multiplication of these values by a factor of $1 \cdot 3$ yields a value not identical with, but roughly approximating Somogyi units.

Mean \pm standard error. Numbers in parentheses denote number of determinations on which normal values are based.

${ }^{3}$ Generally accepted upper limit of normal expressed in Somogyi units.

'Data of Levitt et al (1969). 


\section{Results}

In none of the patients could a serum macroamylase be demonstrated by the chromatographic techniques employed nor by ultracentrifugation in the one case in which this was done. Isoenzyme analysis disclosed a marked rise in activity of the salivary-type isoamylase ('S-type') in all three cases (see table and fig). Pancreatic type ('P-type') was normal in one patient and perhaps slightly above normal in the other two (see table and fig).

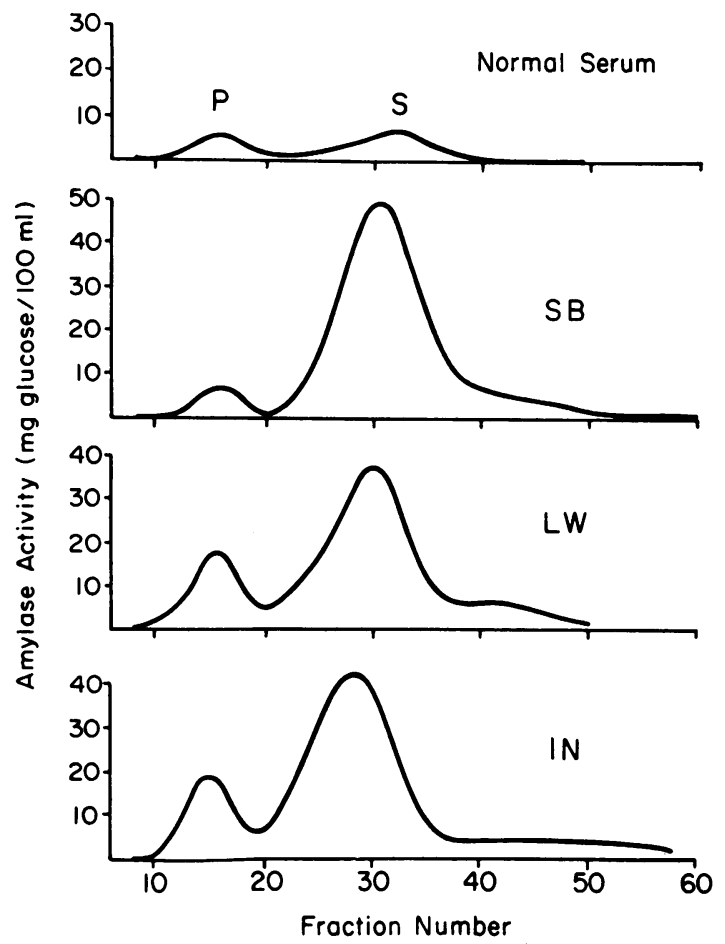

Fig Isoamylase patterns in normal serum and in sera of patients $S B, L W$, and $I N$.

Urine amylase output per hour was well below the accepted upper limit of normal despite the hyperamylasaemia (see table). The ratio of renal amylase clearance to creatinine clearance in each case was below the lowest value found in normal subjects by Levitt and his associates (1969) and within the range of values they found in patients with macroamylasaemia.

\section{Discussion}

Hyperamylasaemia with low or normal urinary amylase excretion in the face of normal renal function has been regarded as the hallmark of macroamylasaemia. The observations made in the three patients described in this report indicate that while hyperamylasaemia and a low ratio of renal amylase clearance to creatinine clearance may arouse suspicion of macroamylasaemia, they do not in themselves unequivocally establish the existence of a circulating macroamylase. As evidenced by the findings in these three patients, elevation in the socalled S-type isoamylase may also be associated with hyperamylasaemia and a low ratio of renal amylase to creatinine clearance. If these criteria alone were accepted, therefore, this condition could be mistakenly identified as macroamylasaemia. Moreover, hyperamylasaemia, which has hitherto been the principal finding prompting consideration of macroamylasaemia as a possible cause, need not necessarily accompany macroamylasaemia. In a prevalence survey conducted by us using a rapid screening method for macroamylasaemia, the existence of a macroamylase was demonstrated in some patients whose total serum amylase values were not raised (Barrows, Berk, and Fridhandler, 1972).

The pathogenesis of S-type hyperamylasaemia is presently obscure. One of our three patients (SB), who consumed large amounts of alcohol, had marked enlargement of both parotid glands. Another (LW), a diabetic, displayed intermittent swelling of both submandibular salivary glands. Whatever the defect accountable for the salivary glandular swelling in these patients, the apparent changes in their salivary glands introduces the possibility that the S-type hyperamylasaemia they displayed resulted from increased salivary output of this isoamylase. Another possible explanation that merits consideration is lowered renal excretion of the S-type isoamylase. That the latter is a real possibility is supported by several lines of evidence that indicate a greater excretory capacity of the kidney for P-type than for S-type isoamylase (Duane, Frerichs, and Levitt, 1972; Fridhandler, Berk, and Ueda, 1972; Kamarýt, 1969). Still another speculative consideration to account for S-type hyperamylasaemia is decreased inactivation of this isoamylase in the serum in vivo.

Whatever the ultimate explanation for so-called S-type hyperamylasaemia may prove to be, the important clinical fact emerging from the observations in our patients is that this type of hyperamylasaemia may exhibit the indirect criteria generally considered to indicate macroamylasaemia and thereby simulate the latter disorder. Henderson, King, and Morgan (1972) have recently described a screening method for macroamylasaemia based upon temperature-activity characteristics. The reliability of this fundamentally indirect method for detecting macroamylasaemia remains, however, to be 
evaluated. For the present, therefore, it must be concluded that unequivocal identification of macroamylasaemia requires the direct demonstration of macroamylase in the serum by chromatography (Berk et al, 1967; Fridhandler, Berk, and Ueda, 1972; Levitt et al, 1969) or some other appropriate method.

This work was supported by a grant from the John A. Hartford Foundation, Inc. The serum and urine samples and the clinical data were kindly supplied by Dr Julius Wenger (case 1), Dr John Galambos (case 2 ), and Dr Thomas Connolly (case 3). Their cooperation in this study is gratefully acknowledged.

References

Barrows, D., Berk, J. E., and Fridhandler, L. (1972). Macroamylasemia-survey of prevalence in a mixed population. New Engl. J. Med., 286, 1352.

Berk, J. E., Kizu, H., Take, S., and Fridhandler, L. (1970). Macroamylasemia: clinical and laboratory features. Amer. J. Gastroent., 53, 211-222.
Berk, J. E., Kizu, H., Wilding, P., and Searcy, R. L. (1967). Macroamylasemia: a newly recognized cause for elevated serum amylase activity. New Engl. J. Med., 277, 941-946.

Duane, W. C., Frerichs, R., and Levitt, M. D. (1972). Simultaneous study of the metabolic turnover and renal excretion of salivary amylase-128I and pancreatic amylase-121 $I$ in the baboon. J. clin. Invest., 51, 1504-1513.

Fridhandler, L., and Berk, J. E. (1970). Automated saccharogenic assay of alpha-amylase activity in serum. Clin. Chem., 16, 911-915.

Fridhandler, L., Berk, J. E., Ueda, M. (1971). Macroamylasemia : rapid detection method. Clin. Chem., 17, 423-426.

Fridhandler, L., Berk, J. E., and Ueda, M. (1972). Isolation and measurement of pancreatic amylase in human serum and urine. Clin. Chem., 18, 1493-1497.

Henderson, A. R., King, J., and Morgan, H. G. (1972). A screening procedure for macroamylasemia (Abstr.). Scand. J. clin. Lab. Invest., 29, Suppl. 126, 21.19.

Kamarýt, J. (1969). Nieren-Clearance der Isoamylasen beim Menschen. Z. klin. Chem. klin. Biochem., 7, 51-52.

Levitt, M. D., Rapoport, M., and Cooperband, S. R. (1969). The renal clearance of amylase in renal insufficiency, acute pancreatitis and macroamylasemia. Ann. intern. Med., 71, 919-925.

Long, W. B., and Kowlessar, O. D. (1972). A rapid thin layer test for macroamylase with observations on the nature of macroamylase in six patients. Gastroenterology, 63, 564-571.

Ueda, M., Berk, J. E., and Fridhandler, L. (1971). Macroamylasemia : variation in the response of the macroamylase complex to acidification. Proc. Soc. exp. Biol. (N.Y.), 137, 1152-1156. 


\section{Notes and activities}

\section{Research in Gastroenterology}

Legal steps are at present being taken to form the British Digestive Foundation from the Digestive Disorders Foundation Trust Fund. The necessary financial support for its first research fellowship has been achieved and the post is being advertised in the medical press.

\section{Seminar on Piles and Perianal Lesions}

The following is the final programme, for this seminar to be held at BMA House on Friday 22 February 1974. The Chairman is $\mathrm{Mr} \mathbf{~ J}$. Alexander-Williams.

MORNING SESSION 10am

10.00 Haemorrhoidectomy, Mr Peter Hawley

10.45 Coffee

11.00 The conservative management of haemorrhoids

Anal dilatation, Mr Peter H. Lord Freezing, Mr K. Lloyd Williams Rubber band ligation, Dr H. M. Liégeois

General discussion and summing up

12.45-1pm Lunch

AFTERNOON SESSION 2pm

2.00 Sexually transmitted diseases of the ano-rectal region, Dr R. D. Catterall

2.45 Fistula, Mr A. G. Parks

3.30 Pruritus ani, Dr Susanne Alexander

4.15 Tea

This seminar has been approved as two sessions under Section 63 of the Health Services and Public Health Act 1968. It will therefore automatically count for the postgraduate training allowance and for seniority payments for general practitioners. The registration fee is $£ 2.50$ to include morning coffee, lunch, and tea.

\section{British Society for Digestive Endoscopy Spring Meeting}

The spring meeting of the British Society for Digestive Endoscopy, 'An evaluation of gastrointestinal fibre-endoscopy', will be held in Bristol on 14 and 15 March 1974.

The programme will include symposia on 'Mucosal cancer', 'Haematemesis and melaena', 'Disorders of the duodenal bulb', 'Jaundice', and 'Inflammatory diseases of the large bowel'. The meeting is open to non-members. For further particulars write to Dr K. F. R. Schiller, Hon. Secretary, British Society for Digestive Endoscopy, St Peter's Hospital, Chertsey, Surrey KT16 0PZ.

\section{Wessex Gut Club}

A meeting of the Wessex Gut Club will be held on 22 February 1974 when Dr John Lennard-Jones will speak. The meeting will be at $5.00 \mathrm{pm}$ in the Post graduate Centre, Southampton General Hospital, and anyone interested is welcome.

\section{European Pancreatic Club}

A meeting of the European Pancreatic Club will take place in Dundee, Scotland, from 4 to 6 July 1974. For further details, please contact: Dr K. G. Wormsley, Maryfield Hospital, Dundee, DD4 7TL, Scotland.

From February 1974 onwards, communications should be addressed to: Dr K. G. Wormsley, Ninewells Hospital, Dundee, DD2 1UB, Scotland.

Ninth Annual Meeting of the European Association for the Study of the Liver

The ninth annual meeting of the European Association for the Study of the Liver will be held from 5 to 7 September 1974 in Hemsedal (Norway). The programme will consist of 36 communications, two symposia, and four working parties.

Information concerning the submission of abstracts can be obtained from the Secretary (Dr Serge Erlinger, Unité de Recherches de Physiopathologie Hépatique, Hôpital Beaujon, F-92110 Clichy, France) as well as all information relating to the meeting.

\section{Asian Society of Colo-rectal Surgery}

The first triennial conference will be held in Bombay, India, on 12, 13 and 14 June 1974, at the Taj Mahal Hotel, Apollo Bunder, Bombay 400001, India.

All information can be obtained from the Chairman, Dr R. K. Menda, Box No. 869, G.P.O., Bombay 400001, India.

First National Congress of the Argentine Federation of Gastroenterology

This Congress will be held in the city of Rosario (Argentine Republic) from 23 to 29 June 1974.
The meeting will consist of symposia, round tables, and sessions on radiology, surgery, endoscopy, and investigation.

Fourth Congress of the Latin American Society of Hepatology

The fourth congress of the Latin American Society of Hepatology will be held in Caracas, Venezuela, on 6, 7, and 8 October 1974. The President is Marta Velasco (Chile).

The official subjects chosen for the meeting are the liver and parasitosis, immunology in liver disease, drugs and the liver, and bile salts.

\section{Notes on books}

Liver Biopsy Interpretation 2nd edition by Peter J. Scheuer, with a Foreword by Professor Sheila Sherlock. (Pp. 184; 110 figures, with 59 in colour. £6.00.) Bailliere Tindall, London. 1973. The second edition of this important book will be widely welcomed. It provides everything which should be known by clinicians and pathologists about liver biopsy and makes a vital contribution towards better management of liver disease in clinical practice.

Inborn Errors of Metabolism edited by F. A. Hommes and C. J. Van Den Berg. (Pp. xv + 375; illustrated. £7.00.) Academic Press, London and New York. 1973. Better understanding of inborn errors of metabolism is particularly important for medical scientists concerned with liver disorders and, to a lesser extent, with problems of intestinal absorption. This publication provides much fundamental information.

\section{Correction}

The authors of 'Simulation of macroamylasaemia by salivary-type ('S type') hyperamylasaemia' (Gut, 1973, 14, 726729) wish to point out that in the final paragraph of their paper the reference to Fridhandler, Berk, and Ueda should be to their report of 1971 not 1972 . Furthermore, the reference to Levitt et al (1969) is an error; the reference should be Long and Kowlessar (1972). 